\title{
Knowledge Economy:
}

\section{Analytical Framework and Policy Implications for Vietnam}

\author{
NGUYẼ̃N TRỌNG HOÀI \\ University of Economics HCMC \\ Email: hoaianh@ueh.edu.vn
}

\section{ARTICLE INFO \\ ABSTRACT}

\section{Article history:}

Received:

June 05, 2013

Received in revised form

July 11, 2013

Accepted:

Dec. 31,2013

Keywords:

knowledge economy, creative innovation, science technology.
The paper presents an analytical framework and indicators measuring progress of the knowledge economy according to the knowledge assessment methodology introduced by the World Bank. Estimations of Vietnam's progress to the knowledge economy show that Vietnam has made great efforts to build the knowledge economy, especially by developing information and communication technologies. However, the gap between Vietnam's knowledge economy and other economies in Asia as well as the world is still wide, especially in such pillars as institutional regime, education, and development of innovation. Vietnam, therefore, should adopt uniform policies on an overall and profound reform in education and technology and in administrative machinery to accelerate the development of knowledge economy. 


\section{THE KNOWLEDGE CONOMY}

In the knowledge economy, according to DTI (1998), creating and using knowledge are crucial in the process of creating physical assets. This is not only an effort to surpass existing knowledge, but also an efficient use of all kinds of knowledge in the economic activities.

Powell \& Snellman (2004) suppose that the knowledge economy is "based on knowledge-intensive activities that contribute to an accelerated pace of technical and scientific advance, as well as rapid obsolescence. The key component of a knowledge economy is a greater reliance on intellectual capabilities than on physical inputs or natural resources."

Suh \& Chen (2007) define a knowledge economy as "one that used knowledge as the key engine of economic growth. It is an economy in which knowledge is acquired, created, disseminated, and used effectively to enhance economic development." Also according to Suh \& Chen, the concept of the knowledge economy "does not necessarily revolve around high technology and information technology. For example, the application of new techniques to subsistence farming can increase yield significantly, or the use of modern logistical services can enable traditional craft sectors to serve broader markets than before."

Thus, the above definitions emphasize that knowledge is the key resource of a knowledge economy compared to other tangible resources. It is as important as, or even more than land and labor in agricultural economy or natural resources and machines in industrial economy due to its non-stopped innovation and creativity in order to improve labor productivity and contribute strongly to the economic growth and its quality.

\section{WORLD PROGRESS TOWARD THE KNOWLEDGE ECONOMY}

Many countries, especially developed ones, have made long and steady progress toward the knowledge economy. According to the WB's 2012 Knowledge Economy Index (KEI), the world's most advanced knowledge economies were Sweeden, Finland, Denmark, Holland, Norway, Canada, Germany, Australia and Switzerland in that order. Common features of these countries are a high-quality education, a modern technological level and infrastructure, transparent and strict law system and great support for innovation and creativity. In Asia, Taiwan held the highest rank $\left(13^{\text {th }}\right)$, followed by Japan $\left(22^{\text {nd }}\right)$, Singapore $\left(23^{\text {rd }}\right)$ and South Korea $\left(29^{\text {th }}\right)$. Particularly, 
development of knowledge economies in Japan and South Korea will provide Vietnam with good lessons.

At present, Japan leads the way in economy, education, and technology. Japan has invested massively in technology. In 2011 particularly, total budget for technology and science is US $\$ 45.6$ billion [1]. With the prime corporations in the world such as Sony, Sumitomo, Mitsubishi, Toyota, etc., Japan is now a leader in the fields of electronics, automobile, industrial robot, optics, chemicals, semiconductors and metals. Moreover, an important contribution to Japan's impressive growth comes from a strong development of education system with many universities ranked among the world's top 200 universities, among which Tokyo University and Kyoto University are the two leading ones. The excellent education system helps Japan win 15 Nobel Prizes in physics, chemistry, medicine, etc. and three Fields Medals in mathematics.

South Korea experienced rapid economic growth in the 1970s based on key industries such as heavy, chemical and then electronics industries. It gained access to important technologies through licensing and original equipment manufacturing contracts. South Korea bases its R\&D foundation on governmental research institutes for absorbing imported technologies and then develops their own new technologies.

All industries have their own contribution to R\&D activities, accounting for $80 \%$ of R\&D expenditure and equaling to 3\% of the GDP (World Bank, 2007). This huge investment helps South Korean corporations become the world's leaders in many fields such as electronic products (Samsung, LG), automobile (Hyundai), and heavy industry (Doosan), strong enough to compete with the US and European leading corporations. During the process of economic development, South Korea has made great investments in education and especially in training skilled and high-quality human resources. Today, Pohang University of Science and Technology and Seoul University in South Korea are among top universities in the world.

\section{THE ROLE OF KNOWLEDGE ECONOMY IN VIETNAM'S DEVELOPMENT IN THE $21^{\text {ST }}$ CENTURY}

After over 25 years of economic reform, Vietnam has obtained considerable achievements in all fields, developing from a poor country into an economy with high growth rates in the world. This extensive growth, however, is based on huge investments in labor-intensive industries enjoying abundant natural resources. This growth model is no longer effective in the globalized economy with technological advances that changed 
drastically human ways of production and consumption. Thus, development of the knowledge economy is considered as a driving force for Vietnam's economy in the $21^{\text {st }}$ century.

In the Socioeconomic Development Strategy for 2011-2020, the VCP defines "The stronger the knowledge economy develops, the more people and knowledge becomes decisive factors of a country's development." In the Platform on National Construction in the Transitional Period to Socialism at the $11^{\text {th }}$ National Congress, it confirmed: "The revolution of modern science and technology, the development of the knowledge economy as well as the globalization and international integration, are opportunities for Vietnam's economic growth. Thus, development in the knowledge economy is defined as one of basic ways to achieve successfully the process of development in the transitional period to socialism until the middle of the $21^{\text {st }}$ century."

According to "Political Report of the $10^{\text {th }}$ Central Executive Committee" at the $11^{\text {th }}$ VCP National Congress: "The development in the knowledge economy is based on development of education, training, science and technology; building up scientist and technological infrastructures, especially information, communications and automation technologies; enhancing R\&D ability in combination with developing high-quality human resources. In addition, Vietnam needs to develop strongly industrial and agricultural products, hi-tech and knowledge-based services with high added value; make the best use of Vietnamese knowledge and exploit the human knowledge to the fullest; and build up and carry out plans to develop the knowledge economy up to 2020."

Thus, the knowledge economy is defined as a main key of Vietnam's economic development in the $21^{\text {st }}$ century. But where is Vietnam among other countries in the evolution toward the knowledge economy and what are the measures to promote the knowledge economy in Vietnam? This paper tries to answer such questions.

\section{ANALYSIS OF PROGRESS TOWARD A KNOWLEDGE ECONOMY}

The knowledge economy is considered as an essential driving force for economic growth in the future. According to World Bank (2007), therefore, it could be built on four pillars: (1) Economic and institutional regime; (2) Education; (3) Innovation system; and (4) Information and communication infrastructure.

Economic and institutional regime: include economic policies and institutions that mobilize and allocate labor, encourage entrepreneurship and stimulate creativity, dissemination and use of knowledge. This pillar covers many policies such as macro 
economy, banking and finance, commerce, labor market, administration, etc. The weakness in an economic and institutional regime can make business environment weak, obscure, corrupt, and lack of motivation and opportunities for creativity. Thus, it will be the largest obstacle to economic and social development generally and a knowledge economy particularly.

Education: a well-educated and skilled labor force is needed for creativity and effective use of knowledge. A system of education and training includes primary schools, secondary schools, vocational school, tertiary education, and lifelong learning. Lifelong learning plays an increasingly important role in the present knowledge revolution. When new knowledge is continuously created, people are required to improve skills at the speed of human knowledge development. Lifelong learning is the only way to help workers develop their skills, catch up with the world's advanced technology, as well as help developing countries catch up with developed countries for competitiveness.

Innovation system includes firms, research centers, universities and other organizations that approach and keep up with new knowledge and technology to adapt and use it for local needs. Additionally, support for technological and scientific innovations also involves several factors from infrastructure to regime and from dissemination of basic technology to advanced research activities. In developing countries, most knowledge and techniques of innovation system are gathered from foreign sources as FDI sectors, machines and equipment imported from developed countries and licensing agreements.

Information and communication infrastructure: a modern and adequate information infrastructure is a good condition for effective communication, processing and dissemination of information. Information and communication technologies (ICTs), including telecommunications, broadcast media, radio and internet are essential infrastructures of the information-based global economy in the $21^{\text {st }}$ century, and it is as important as networks of railways, roads and water and power supplies in the $20^{\text {th }}$ century. These infrastructures may reduce transactions costs by providing access to information anytime and anywhere. Information and technology policies include regulations on telecommunications and important investments to create and exploit information and broadcast technologies through such e-applications as e-government, ebusiness, and e-learning, etc. 
The relationship between four pillars is presented in Figure 1. Economic and institutional regime plays the role of a foundation for development of the other three pillars. Only if an economic and institutional regime that encourages, nurtures and supports development of new knowledge, innovation and creativity can the knowledge economy have a good opportunity to develop.

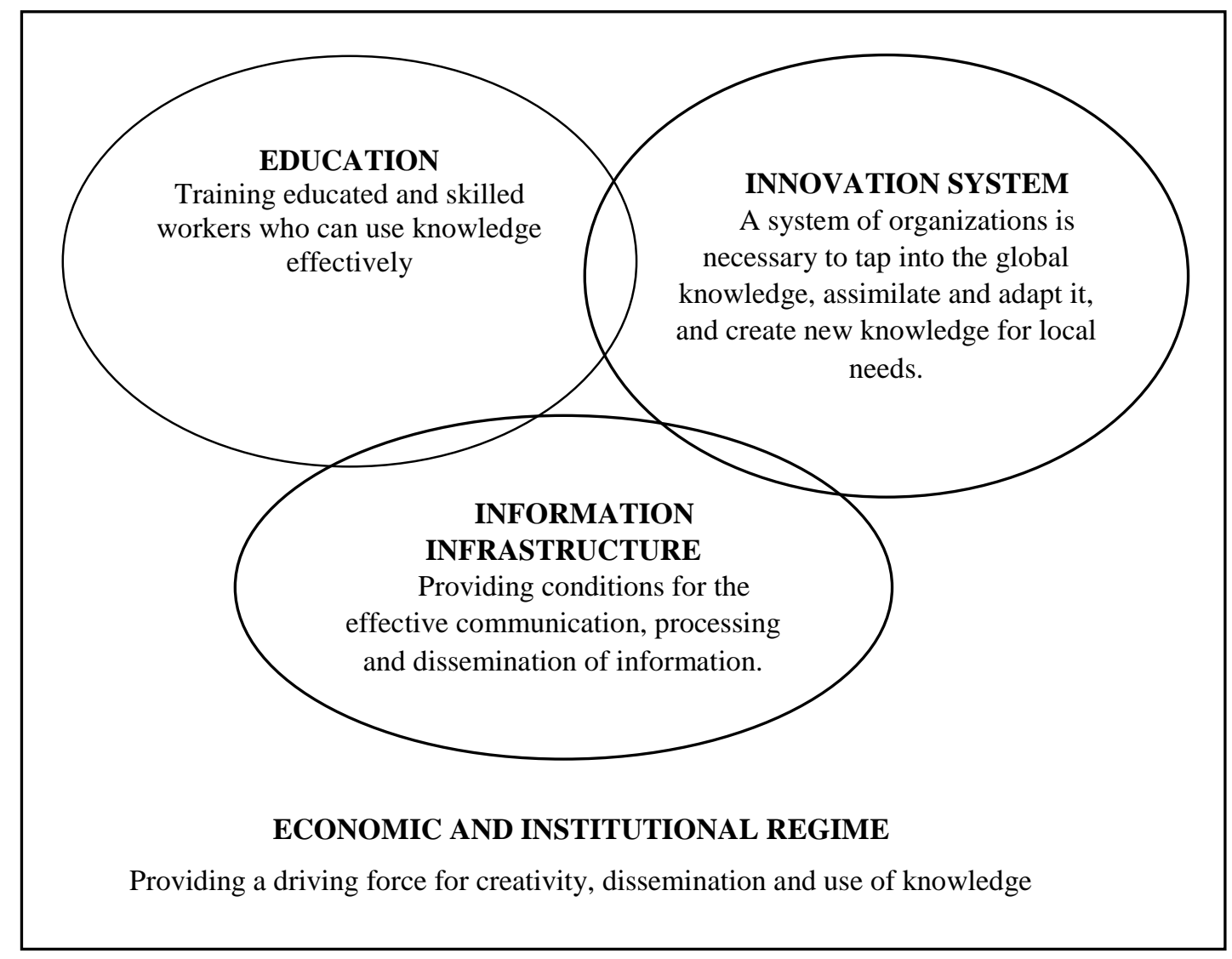

Figure 1: Analytical Framework of Knowledge Economy Pillars

Source: World Bank (2007)

Moreover, there are close interactive relationships between these pillars. For example, a society must achieve certain level of development in education to obtain certain level of human capital before developing an effective system of research and creativity or improving labor productivity due to investments in modern information and technology infrastructure. Similarly, it is difficult for the innovation system to benefit from the global knowledge if information and communication infrastructure is not 
sufficient. Thus, it is necessary to make balanced investments in four pillars for the development of knowledge economy and additionally, combine all of them to improve achieved results.

\section{MEASUREMENT OF PROGRESS TOWARD KNOWLEDGE ECONOMY}

Long-term strategies are required to develop a knowledge economy and promote its four pillars, so it is necessary to establish variables for measuring strengths and weaknesses of each pillar thereby helping policy makers select right policies. In addition, variables for measuring progress by each country in every pillar are also needed. In order to achieve this aim, World Bank Knowledge for Development Program developed an interactive benchmarking tool to measure performance of each country on the four knowledge economy pillars, called Knowledge Assessment Methodology (KAM) (World Bank, 2012). This is an internet-based tool that can measure level of preparation of each country for a knowledge economy. Additionally, it helps countries evaluate their strengths and weaknesses based on the four knowledge economy pillars by comparing themselves with others countries. According to World Bank Institute, KAM allows the policy makers to identify the problems and opportunities their countries may face in making a transition to the knowledge economy. At present, KAM is applied to measure 146 countries.

\section{- KAM's indexes}

KAM also develops indexes besides 148 variables to reflect a country's overall progress toward the knowledge economy generally and in each group of variables particularly. In addition to Knowledge Economy Index (KEI) [3] and Knowledge Index (KI), the two most important overall indexes, there are indexes for the pillars of a knowledge economy, including Economic and Institutional Regime Index, Education Index, Innovation Index and ITC Index. Each index is calculated by a mean value of three variables in each pillar that are presented in Figure 2, in which we can see that KEI is calculated by 12 key variables of the four pillars. 


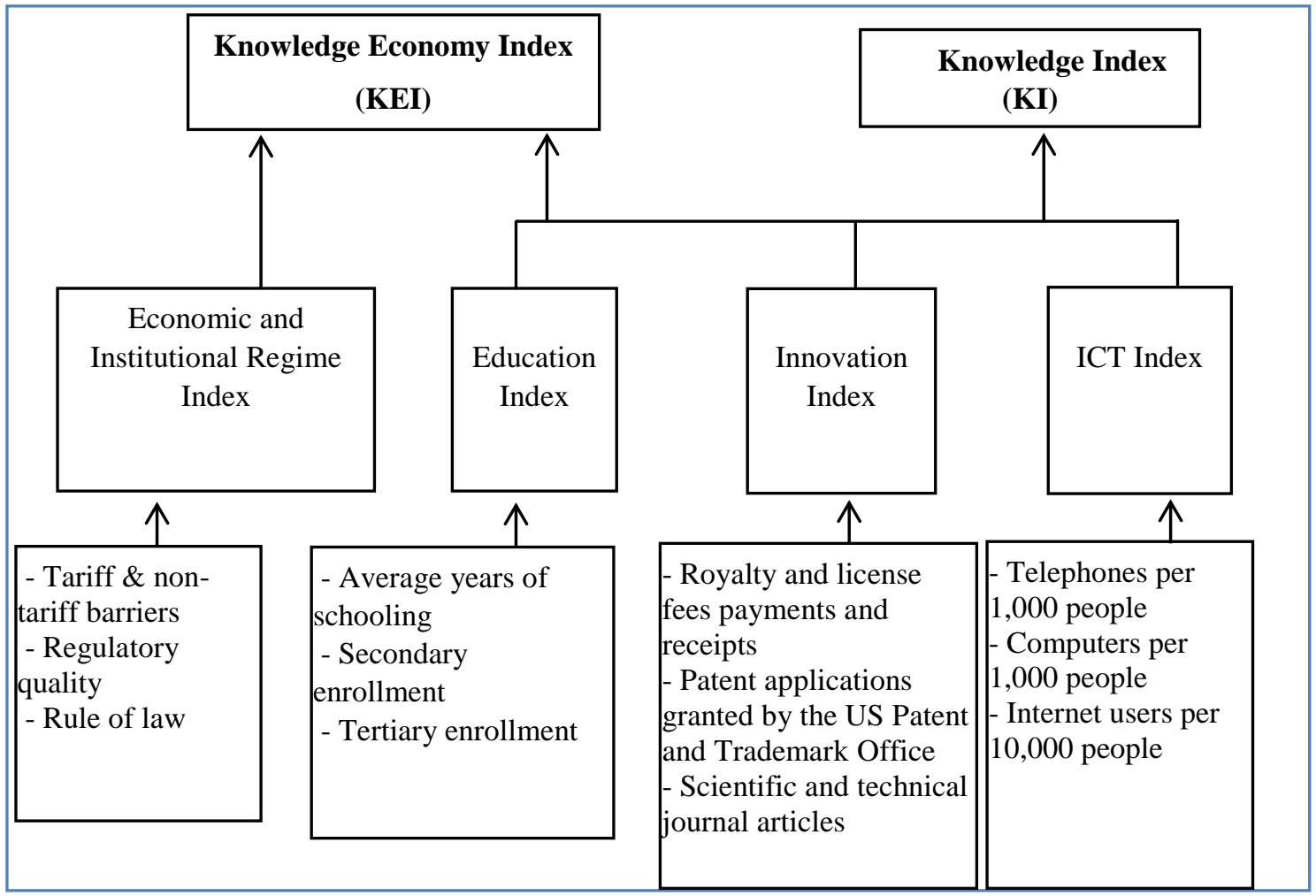

Figure 2: Knowledge Indexes

Source: World Bank (2012b)

\section{- Normalization of data}

In 2012, KAM includes 148 [2] variables to measure countries' performance on the four KI pillars, economic situation and labor force. All variables are normalized on scale of 0 to 10 and their normalization procedure is as follow:

- The actual data $(\mathrm{u})$ is collected from datasets of World Bank or other resources for 148 variables and 146 countries.

- Ranks are allocated to countries based on the absolute values of each variable. Countries with the same absolute values are allocated the same rank. Thus, a country in the $1^{\text {st }}$ place performs the best among the countries on a particular variable, a country in the $2^{\text {nd }}$ place performs second best, and so on.

- The number of countries with lower rank $(\mathrm{Nw})$ is calculated for each country. 
- The following formula is used to normalize the scores for each country on every variable, based on country's rank and the number of countries in the sample (Nc) with available data:

$$
\text { Normalized }(u)=10\left(\frac{N w}{N c}\right)
$$

- The above formula allocates a normalized score from 0 (the worst) to 10 (the best) for 146 countries on every variable among 148 ones. The top $10 \%$ of countries performing the best receive a normalized score between 9 and 10, the second best $10 \%$ of countries gets normalized scores between 8 and 9 and so on (World Bank, 2007).

\section{VIETNAM'S PROGRESS TOWARD KNOWLEDGE ECONOMY}

Vietnam has made some modest progress toward the knowledge economy. It advanced nine steps from the $113^{\text {th }}$ in 2000 to $104^{\text {th }}$ position in 2012 with KEI of 3.4. Its rank, however, was much lower than Singapore, Malaysia, Thailand and the Philippines, ranked respectively $23^{\text {rd }}, 48^{\text {th }}, 66^{\text {th }}$ and $92^{\text {nd }}$ among 146 countries, and its normalized score was lower than the Asia- Pacific average of 5.32.

Table 1 shows Vietnam's performance on the four KI pillars in making the transition to the knowledge economy over time. In the period 1995-2012, its ICT pillar was improved while the others did not change much. Particularly, Vietnam rose 38 positions to $75^{\text {th }}$ place between 2000 and 2012 with a normalized score of 5.05 because of its strongest performance in the ICT pillar. This was the only pillar that received a normalized score up to 5, and it was also considered the best performance among four pillars. Meanwhile, its EIR pillar and Education pillar did not change much , ranking $108^{\text {th }}$ (normalized score of 2.8 ) and $105^{\text {th }}$ (normalized score of 2.99) respectively in 2012. Vietnam's Innovation pillar is the weakest among the four KI pillars, rising from $117^{\text {th }}$ place (normalized score of 2.4) in 2000 to $113^{\text {th }}$ place (normalized score of 2.75) in 2012.

Table 1: Vietnam's Advances in Four Pillars

\begin{tabular}{lccc}
\hline & $\mathbf{2 0 1 2}$ & $\mathbf{2 0 0 0}$ & $\mathbf{1 9 9 5}$ \\
\hline Economic and Institutional Regime Index & 2.8 & 2.74 & 2.64 \\
Education Index & 2.99 & 2.82 & 2.28 \\
Innovation Index & 2.75 & 2.4 & 2.34 \\
ICT Index & 5.05 & 2.92 & 4.5 \\
\hline
\end{tabular}

Source: World Bank (2012a) 
Table 2 analyzes in detail 12 variables for Vietnam's four KI pillars over years.

Economic and institutional regime: generally, Vietnam made no progress in this pillar where tariff and nontariff barriers received the lowest normalized score of 1.82 among its three variables. This did not imply that Vietnam's position was fallen compared to 2000 , but compared to other advanced countries, Vietnam's normalized score was relatively lower. Its regulatory quality made a relative advance, rising from 1.79 points in 2000 to 2.26 in 2012, which reflected its advances in public administration reform, law improvement and transparency in finance and banking sector. In addition, its variable for rule of law received the highest normalized score of 4.32 in 2012 compared with other two variables, but no significant change compared to 2000 (normalized of 4.34) took place.

Education: all three variables for this pillar improved in absolute values. Specifically, average years of schooling rose from 5.11 scores in 2000 to 6.43 scores in 2012; tertiary enrollment rose from $9.6 \%$ in 2000 to $15.94 \%$ in 2012 . However, such variables were still lower than other countries in the world because they have not reflected the quality of education, a key factor of Vietnam's knowledge economy development.

Table 2: Variables for Four Pillars of Vietnam's Knowledge Economy

\begin{tabular}{llll}
\hline & $\mathbf{2 0 1 2}$ & $\mathbf{2 0 0 0}$ & $\mathbf{1 9 9 5}$ \\
\hline Tariff and nontariff barriers & 1.82 & 2.07 & 1.86 \\
Regulatory quality & 2.26 & 1.79 & 2.87 \\
Rule of law & 4.32 & 4.34 & 3.19 \\
$\begin{array}{l}\text { Royalty payments and receipts } \\
\text { (US\$/population) }\end{array}$ & & & \\
S\&T journal articles/million people & 2.62 & 1.92 & 1.52 \\
$\begin{array}{l}\text { Patents granted by USPTO/ million } \\
\text { people }\end{array}$ & 2.88 & 2.88 & 3.17 \\
Average years of schooling & 2.2 & & \\
Secondary enrollment rate & 3.52 & 3.52 & 3.89 \\
Tertiary enrollment rate & 3.26 & 3.03 & 1.82 \\
Total telephones per 1,000 people & 6.21 & 2.48 & 2.55
\end{tabular}




$\begin{array}{llll}\text { Computers per } 1,000 \text { people } & 4.52 & 3.45 & 3.49 \\ \text { Internet users per } 1,000 \text { people } & 4.41 & 2.83 & 7.45\end{array}$

Source: World Bank (2012a)

Innovation system: these variables ranked the lowest among Vietnam's four KI pillars. Particularly, science and technical journal articles per million people increased from 1.92 in 2000 to 2.62 in 2012 which were lower than Thailand (normalized score of 25.79 articles) and Malaysia (30.43). Vietnam's normalized score for patents granted by USPTO (per million people) was 0.01 that was lower than Thailand (normalized score of 0.51) and Malaysia (normalized score of 5.63). Such numerals have reflected a restriction in research and creation capacity of Vietnam's economy - an important promotion for making the transition to the knowledge economy.

Information and communication technology was the Vietnam's most advanced pillar. Considered as one of the countries making the fastest development in information and communication technology in the world, Vietnam made impressive improvement in this pillar. Its total telephones and computers per 1,000 people rose more than 30 times from 40 to 1,360 and tenfold from 10 to 100 , respectively between 2000 and 2012, and its number of internet users per 1,000 people were 270 people (per 1,000 people) in 2012.

There is a correlation between advances in the knowledge economy of Vietnam and other countries when we make a comparison between economies of Vietnam and of Thailand, Malaysia, and Indonesia.

It is easy to see that the gap between Vietnam and Malaysia as well as Thailand is rather large in all variables except information technology and communication indicators. For example, total telephones per thousand people of Vietnam received a normalized score of 6.21 compared to those of Malaysia and Thailand with 5.93 and 6.14 respectively. Its normalized score (4.41) for Internet users per 1,000 people was higher than Thailand (4.28) but lower than Malaysia (7.59). Compared to Indonesia, Vietnam has made a stronger performance in information and communication indicators and a similar performance in the others. 
Table 3: Progress toward the Knowledge Economy of Vietnam, Thailand, Malaysia and Indonesia

\begin{tabular}{lcccc}
\hline & VN & Indonesia & Thailand & Malaysia \\
\hline Tariff and nontariff barriers & 1.82 & 3.36 & 3.99 & 4.62 \\
Regulatory quality & 2.26 & 3.56 & 5.96 & 5.68 \\
Rule of law & 4.32 & 3.49 & 5.41 & 6.71 \\
$\begin{array}{l}\text { Royalty payments and receipts } \\
\text { (US\$/population) }\end{array}$ & & 5.12 & 6.8 & 7.28 \\
$\begin{array}{l}\text { S\&T journal articles/ million } \\
\text { people }\end{array}$ & 2.62 & 0.83 & 5.17 & 5.45 \\
$\begin{array}{l}\text { Patents granted by USPTO/ million } \\
\text { people }\end{array}$ & 2.88 & 3.77 & 5.89 & 8.01 \\
Average years of schooling & 2.2 & 2.05 & 3.15 & 7.32 \\
Secondary enrollment rate & 3.52 & 3.72 & 3.45 & 3.1 \\
Tertiary enrollment rate & 3.26 & 3.83 & 6.1 & 5.25 \\
Total telephones per 1,000 people & 6.21 & 3.38 & 6.14 & 5.93 \\
Computers per 1,000 people & 4.52 & 1.64 & 6.23 & 6.3 \\
$\begin{array}{l}\text { Internet users per 1,000 people } \\
\text { Sor }\end{array}$ & 4.41 & 2.55 & 4.28 & 7.59 \\
\hline
\end{tabular}

Source: World Bank (2012a)

In short, Vietnam has made great efforts to advance toward the knowledge economy, especially in ICT. However, the gap in the knowledge economic growth between Vietnam and other countries in the world is large. Thus, it should try to improve the situation in the future, especially in its institutional regime, the quality of education and innovation system.

\section{POLICY IMPLICATIONS}

Estimates of Vietnam's progress toward the knowledge economy allow suggestion of the following policy implications to improve the knowledge economy in Vietnam:

Firstly, Vietnam should improve its market economy and legal framework according to international practices and WTO's regulations to create a fair and transparent business 
environment, protect intellectual property and encourage entrepreneurship, promoting innovation and creation in all sectors.

Secondly, it is necessary to carry out an overall reform in education and training of all levels, especially the tertiary education. Additionally, development of the higher education in Vietnam should be based on international standards in management, training, evaluation and scientific research. Moreover, it should strive to strengthen several universities that can be included in the top 200-500 ones in the world, and create the best conditions for the major universities to train high-quality human resources to work in the knowledge economy. Vietnam should also adopt policies to persuade excellent professors or experts from abroad to join in teaching and research in Vietnam.

Thirdly, introduce long-term strategies for the techno-scientific development. Particularly, it is essential to link research with application and development of a market for scientific and technological researches. Other measures include absorbing effectively foreign advanced technologies through cooperation, trade and technology transfer; encouraging scientific researches and technology replacement in all sectors; building armies of techno-scientific experts and research institutes of international standards; and focusing on key industries of the knowledge economy such as information technology, automation technology, biotechnology, and new materials and energy technology.

Finally, information and communication infrastructure and IT applications need to be further developed. Incentives could be given to IT applications in all fields, especially administration and e-government. Developing well-skilled IT human resources to meet requirements by the knowledge economy is an urgent task that requires strategies to develop IT and software engineering into a key industry and enhance export value of IT products as the principal measure to improve Vietnam's competitiveness in the $21^{\text {st }}$ century

\section{Note:}

[1] http://truyenthongkhoahoc.vn/vn/Truyen-thong-khoa-hoc-Nhat-Ban-Vai-net-cham-phac1043/Truyen-thong-khoa-hoc-Nhat-Ban-Vai-net-cham-pha-n3579

[2] Details of the indicators are available at http://info.worldbank.org/etools/kam2/KAM_page3.asp?default=1 
[3] The KEI index is the most general index, calculated for each country. It is an aggregate index representing a country's overall development in the knowledge economy. The KEI index reflects a country's performance in the four KI pillars and is their average value.

\section{References}

VCP (2011), Báo cáo chính trị của Ban Chấp hành Trung uoong Đảng khoá X (Political Report of the $10^{\text {th }}$ Central Executive Committee) presented at the $11^{\text {th }}$ VCP National Congress.

VCP (2011), Chiến lược phát triển kinh tế - xã hội 2011 - 2020 (Socioeconomic development strategy for 2011 - 2020) presented at the $11^{\text {th }}$ VCP National Congress

VCP (2011), Cuơng lĩnh xây dưng đất nước trong thờ kì quá độ lên chủ nghĩa xã hội (Platform for national construction in the transitional period to socialism) presented at the $11^{\text {th }}$ VCP National Congress

DTI (UK Department of Trade and Industry) (1998), Building the Knowledge Driven Economy, London DTI, http://www.dti.gov.uk/comp/competitive/.

Powell, W. W. \& K. Snellman (2004), “The Knowledge Economy”, Annual Review of Sociology, 30(1), pp. 199-220.

Suh, J., \& D. H. C. Chen (2007), Korea as a Knowledge Economy: Evolutionary Process and Lessons Learned, World Bank Institute Development Studies.

World Bank (2007), Building Knowledge Economies: Advanced Strategies for Development, World Bank Institute Development Studies.

World Bank (2012a), Knowledge Assessment Methodology 2012, World Bank, http://go.worldbank.org/JGAO5XE940

World Bank (2012b), Knowledge Economy Index (KEI) 2012 Rankings,

World Bank.http://siteresources.worldbank.org/INTUNIKAM/Resources/2012.pdf 